\title{
変動摩擦係数を伴うしゅう動接触による被覆材の非定常熱応力*
}

\author{
五嶋 孝 仁*1, 石原外美*2,田村 清*3 \\ 清 水理能*2, 舘 ゆかり*4
}

\section{Transient Thermal Stresses of Coated Materials due to Sliding Contact with Changing Frictional Coefficient}

\author{
Takahito GOSHIMA*5, Sotomi ISHIHARA, Kiyoshi TAMURA, \\ Masayoshi SHIMIZU and Yukari TACHI \\ ${ }^{* 5}$ Faculty of Engineering, University of Toyama, \\ 3190 Gofuku. Toyama-shi. Toyama, 930-8555 Japan
}

\begin{abstract}
This paper deals with the transient thermal stresses of a surface layered material due to the sliding contact with changing frictional coefficient. The actual frictional coefficient is given by the experimental results of the sliding-contact test on the bearing-specimen lined with white metal. The temperature and thermal stresses caused by the frictional heat generation in a coated materials are analyzed by making use of Laplace transformation and Duhamel integration. Numerical calculations are carried out for the same conditions of the examples in the sliding contact test. It became clear that the numerical results of temperature agreed well with the experimental results by choosing the proper heat transfer coefficient and the variations of temperature were similar to the change of frictional coefficient. Moreover, the thermal effects on the stress variations are considered by comparing the results of thermal stresses with the results of mechanical stresses.
\end{abstract}

Key Words : Elasticity, Thermal Stresses, Sliding Contact, Coated Material, Frictional Heat

\section{1. 緒言}

船舶用ホワイトメタル軸受や新幹線車両用ブレーキ のクラッドディスクなど，しゅう動接触を受ける被覆 材では摩耗特性向上の一方で, 摩擦熱に起因して被覆 材に生じる熱応力が損傷発生の大きな原因となってい る.摩擦熱などによる熱応力を伴う摩擦接触を受ける 被覆材に関しては, Ju ら ${ }^{(1)}$ が初めて, 摩擦熱を伴う移 動接触荷重を受ける被覆半無限体の熱弾性問題を解析 している.続いて Juら (2)は同じモデルについて， 種々のトライボロジー材料に対する熱応力に及ぼすぺ クレ数や被覆厚さの影響など，具体的な計算例を報告 している.また, Chen ら ${ }^{(3)}$ は, 周期的に移動する摩 擦接触荷重による非定常熱応力を解析している.さら に，長時間のしゅう動接触を受けるような場合には， 微小摩耗の進行により表面の粗さや形状が変化して, 摩擦係数が時間とともに変化することが多い.このた

\footnotetext{
* 原稿受付 2006 年 1 月 30 日.

*1 正員, フェロー, 富山大学工学部 (\$9 930-8555 富山市五福 3190).

*2 正員, 富山大学工学部.

*3 正員, 日本マリンテクノ(株) (业 930-0992 富山市新庄町 714-37).

*4 YKK (株) (恶 933-0005 黒部市吉田 200).

E-mail : goshima@eng.toyama-u.ac.jp
}

めMolinari ら (4) は，すべり接触条件による摩擦係数 の変化について報告しているが, 高速の場合に限られ, 非定常的な摩擦係数の変化およびそれによって生じる 熱応力までは解析していない. また, 最近 Liu ら (5)(6) が, 実際の表面粗さを考慮した二次元および三次元モ デルについて, 熱弾性問題を解析している. 彼らは粗 さによる厳密な熱発生分布を考慮しているが, 準定常 問題を扱っており，また摩擦係数は一定として解析し， 摩擦係数の変動までは取扱っていない.

そこで本研究では, 摩擦係数が時間とともに変化す るしゅう動接触を受ける被覆材の非定常熱応力を解析 し, 温度ならびに応力の一般解を導いた. 具体例とし て, ホワイトメタルライニング軸受材のしゅう動摩擦 実験 ${ }^{(7)}$ を行い, 温度および摩擦係数を測定した.この 変動摩擦係数の測定値を利用し, 実験条件に対応した 境界条件のもとで, 上述の一般解より温度および非定 常熱応力の数值結果を求め, 温度変動の数値結果と実 験結果を比較した.さらに, これらの温度変動を摩擦 係数変動の測定結果と比較することにより, 温度変動 を用いて摩擦係数変動を推定できる可能性を検討し た. また, この温度場による非定常熱応力と接触応力 による機械的応力を比較し, 熱応力が全応力に及ぼす 定量的影響を検討した.さらに, 全く同様な境界条件 
のもとで, 均一材の非定常熱応力の数値計算結果とも 比較検討した.

\section{2. 解析モデルと境界条件}

ライニングすべり軸受などに関連し，被覆材表面が 軸の回転によりしゅう動接触を受ける場合について, 図 1 に示すように幅 $2 c$ の接触領域で接触圧力, 摩擦 応力および摩擦熱を受けている解析モデルを考える. 解析に当たっては, 以下に示す無次元変数を用いる.

$$
\begin{aligned}
& (x, y)=(\tilde{x} / c, \quad \tilde{y} / c), \quad h=\tilde{h} / c, \quad \tau=\varkappa_{1} t / c^{2} \\
& B_{0}=\gamma_{1} c / K_{1}, \quad \varkappa=\varkappa_{2} / \varkappa_{1}, \quad K=K_{2} / K_{1} \\
& G=G_{2} / G_{1}, \quad E=E_{2} / E_{1}, \quad \nu_{0}=\nu_{2} / \nu_{1} \\
& P_{1}(x)=P(\tilde{x}) / P_{0}, \quad \Gamma_{j}=\left(1+\nu_{j}\right) \alpha_{j} /\left(1-\nu_{j}\right)
\end{aligned}
$$

ここで, $t$ は時間, $K_{j}$ は熱伝導率, $\varkappa_{j}$ は温度伝導率, $\alpha_{j}$ は線膨張係数, $G_{j}$ は横弾性係数, $E_{j}$ は縦弾性係数, $\nu_{j}$ はポアソン比, $\gamma_{j}$ は熱伝達率, $n$ は軸の回転速度, $V$ は軸の周速度, $\tau$ はフーリエ数, $B_{0}$ はビオ数, $P_{1}(x)$ は無次元接触圧力であり, ここではへルッ分布 と仮定し， $P_{0}$ はヘルツ最大接触圧力を表す.

また, 摩擦係数 $f$ は次式のように時間的に変化する 関数 $F(\tau)$ で表す。なお, 後述のように, 数值計算で は $F(\tau)$ は実際の実験結果を用いて求める.

$$
f=F(\tau), \quad(\tau>0)
$$

また, 摩擦仕事がすべて熱に変換されるものとすれ ば, 接触面で発生する摩擦熱は次式で与えられる.

$$
q(x)=V f P(\tilde{x})=V P_{0} P_{1}(x) F(\tau), \quad(\tau>0)
$$

時間 $\tau=0$ のとき熱応力は零で, そのときの温度を 基準温度とすれば, 温度の初期条件は次式となる。

$$
\left(T^{(j)}\right)_{\tau=0}=0
$$

一般に式 ( 2 )の接触面発生摩擦熱は, 接触の状態に よって試験片, 接触物体, 雲囲気中にそれぞれある割

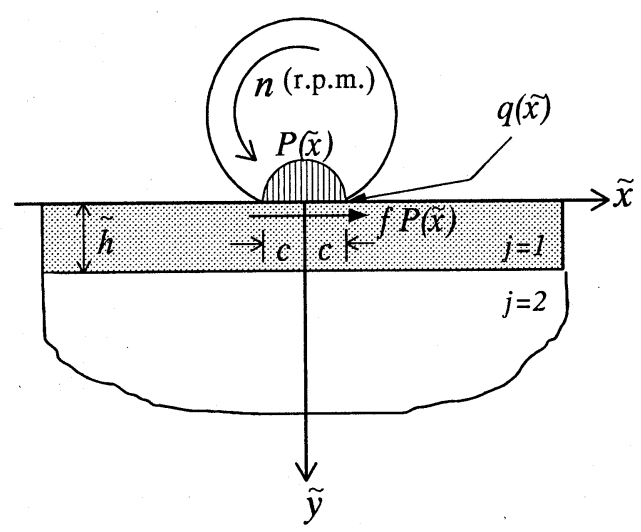

Fig. 1 Geometry and coordinate system
合で熱が伝達するものと思われる。そこで, 試験片に 流入する熱流の割合を $\eta[\%]$ とすれば，熱的境界条件 は次式で与えられる。

$$
\begin{aligned}
& \left(\frac{\partial T^{(1)}}{\partial y}\right)_{y=0}-B_{0}\left(T^{(1)}\right)_{y=0}=\left\{\begin{array}{l}
-T^{*} f P_{1}(x), \quad|x| \leq 1 \\
0, \quad|x|>1
\end{array}\right. \\
& T^{*}=\frac{c V P_{0}}{K_{1}} \times \frac{\eta}{100}
\end{aligned}
$$

また, 力学的境界条件は以下のように表される。

$$
\begin{aligned}
& \left(\sigma_{y y}^{(1)}\right)_{y=0}=\left\{\begin{array}{l}
-P_{0} P_{1}(x), \quad|x| \leq 1 \\
0, \quad|x|>1
\end{array}\right. \\
& \left(\sigma_{x y}^{(1)}\right)_{y=0}=\left\{\begin{array}{l}
f P_{0} P_{1}(x), \quad|x| \leq 1 \\
0, \quad|x|>1
\end{array}\right. \\
& \left(\sigma_{y y}^{(1)}\right)_{y=h}=\left(\sigma_{y y}^{(2)}\right)_{y=h} \\
& \left(\sigma_{x y}^{(1)}\right)_{y=h}=\left(\sigma_{x y}^{(2)}\right)_{y=h} \\
& \left(u_{x}^{(1)}\right)_{y=h}=\left(u_{x}^{(2)}\right)_{y=h} \\
& \left(u_{y}^{(1)}\right)_{y=h}=\left(u_{y}^{(2)}\right)_{y=h} \\
& \left(\sigma_{x x}^{(j)}, \sigma_{y y}^{(j)}, \sigma_{x y}^{(j)}\right)_{x^{2}+y^{2}-\infty}=0
\end{aligned}
$$

\section{3. 温度および応力解析}

$3 \cdot 1$ 変動摩擦係数による温度および応力解 求 める応力解 $\left\{\sigma_{p q}^{(j)}\right\}$ は, 次式のように接触荷重による機 械的応力 $\left\{{ }^{P} \sigma_{p q}^{(j)}\right\}$ と, 表面応力自由の熱応力 $\left\{{ }^{T} \sigma_{p q}^{(j)}\right\}$ を重 ね合わせて求められる。

$$
\left\{\sigma_{p q}^{(j)}\right\}=\left\{{ }^{P} \sigma_{p q}^{(j)}\right\}+\left\{{ }^{T} \sigma_{p q}^{(j)}\right\}, \quad(p, q=x, y)
$$

変動摩擦係数による接触荷重によって生じる機械的 応力 $\left\{{ }^{P} \sigma_{p q}^{(j)}\right\}$ は, 式 $(10)$ 中の $f$ を $F(\tau)$ と置換え, 境界 条件式 $(9)$ ～(15) を満足する弾性問題を直接解くこと により, 準定常解が求められる. しかし, 温度 $T^{(j)} お$ よび熱応力 $\left\{{ }^{T} \sigma_{p q}^{(j)}\right\}$ は非定常解となり, 式 (1)の $f$ が単 位ステップ関数で与えられた場合の温度解 $T_{S}^{(j)}$ およ び非定常熱応力解 $\left\{{ }^{S} \sigma_{p q}^{(j)}\right\}$ が求まれば, 次のデュアメル 積分により求めることができる.

$$
\begin{aligned}
& T^{(j)}(\tau)=\int_{0}^{\tau} F(\lambda) T_{s}^{(j)}(\tau-\lambda) \mathrm{d} \lambda \cdots \\
& \left\{{ }^{T} \sigma_{p q}^{(j)}(\tau)\right\}=\int_{0}^{\tau} F(\lambda)\left\{{ }^{s} \sigma_{p q}^{(j)}(\tau-\lambda)\right\} \mathrm{d} \lambda
\end{aligned}
$$

ただし, $\left\{{ }^{T} \sigma_{p q}^{(j)}\right\}$ と $\left\{{ }^{S} \sigma_{p q}^{(j)}\right\}$ は被覆材表面で応力自由であ り, 式(11)〜 (15) の境界条件を満たすものとする.

$3 \cdot 2$ ステップ状変動摩擦係数による温度解 境 界条件式 $(4)$ 中の $f$ を単位ステップ関数に置換えた境 
界条件式 ( 4 ) （８）と, 初期条件式 ( 3 )のもとで次式の熱伝導方程式を解けば, $T_{S}^{(j)}$ を求めることができる.

$$
\frac{\partial^{2} T_{s}^{(j)}}{\partial x^{2}}+\frac{\partial^{2} T_{s}^{(j)}}{\partial y^{2}}=\delta_{k}^{(j)} \frac{\partial T_{s}^{(j)}}{\partial \tau}, \quad(j=1,2)
$$

ここで, $\delta_{k}^{(1)}=1, \delta_{\kappa}^{(2)}=1 / \varkappa$ でる. 式 $(3)$ を参考にして $\tau$ に関してはラプラス変換を用い, $x$ に関してはフーリエ $\cos$ 変換を用いれば, 式(19)の境界值問題の解が求まり, 次式のように表される.

$$
T_{S}^{(j)}=T^{*} \frac{2}{\pi} \int_{0}^{\infty} P_{2}(\xi)\left[2 \delta_{01}^{\kappa} \sum_{n=1}^{N_{\varepsilon}} \frac{r_{n}\left(1-e^{-\left(\xi^{2}+r^{2}\right) \tau}\right)}{\left(\xi^{2}+r_{n}^{2}\right) f_{0}\left(r_{n}\right)} R_{n}^{(j)}(y)+\frac{2}{\pi} \int_{0}^{\infty} \frac{\varepsilon\left(1-e^{-\kappa\left(\xi^{2}+\varepsilon^{2}\right) \tau}\right)}{\left(\xi^{2}+\varepsilon^{2}\right)} S_{\varepsilon}^{(j)}(y) \mathrm{d} \varepsilon\right] \cos (x \xi) \mathrm{d} \xi
$$

ここで $\delta_{01}^{\kappa}=1(\kappa>1), \delta_{01}^{\kappa}=0(\kappa \leq 1)$ であり, $r_{n}$ は次式の $n$ 番めの正根である. ただし, $r_{n}<\xi \sqrt{\varkappa-1}$ の条件を満足 する正根の数を $N_{\xi}$ とする.

$$
\begin{aligned}
& \tan (r h)=\frac{r\left(B_{0}+K \beta_{2}\right)}{r^{2}-B_{0} K \beta_{2}}, \quad \beta_{2}=\sqrt{\xi^{2}-\frac{\left(\xi^{2}+r^{2}\right)}{\varkappa}} \\
& f_{0}(r)=\left[r^{2} h+K\left(\frac{r^{2}}{\varkappa \beta_{2}}-\beta_{2}\right)-B_{0}\left(1+K \beta_{2} h\right)\right] \cos (r h)+\left[r\left(2+K \beta_{2} h\right)+B_{0} r\left(h+\frac{K}{\kappa \beta_{2}}\right)\right] \sin (r h) \\
& R_{n}^{(1)}(y)=r_{n} \cos (h-y) r_{n}+K \beta_{2} \sin (h-y) r_{n}, \quad R_{n}^{(2)}(y)=r_{n} e^{-(y-h) \beta_{2}} \\
& P_{2}(\xi)=\int_{0}^{1} P_{1}(x) \cos (\xi x) \mathrm{d} x
\end{aligned}
$$

また $S_{\varepsilon}^{(j)}(y)$ は各場合によって次のように表される.

(1) $\varkappa \geq 1$ または $x<1$ で $\varepsilon \leq \varepsilon_{0}=\xi \sqrt{(1-\varkappa) / \varkappa}$ のとき

$$
\begin{aligned}
& S_{\varepsilon}^{(1)}(y)=\frac{K \varepsilon \nu}{D_{\nu}(\varepsilon)}\left\{\left[\nu \cos (\nu h)+B_{0} \sin (\nu h)\right] \cos (h-y) \nu+\left[\nu \sin (\nu h)-B_{0} \cos (\nu h)\right] \sin (h-y) \nu\right\} \\
& S_{\varepsilon}^{(2)}(y)=\frac{\nu}{D_{\nu}(\varepsilon)}\left\{K \varepsilon\left[\nu \cos (\nu h)+B_{0} \sin (\nu h)\right] \cos (y-h) \varepsilon+\nu\left[\nu \sin (\nu h)-B_{0} \cos (\nu h)\right] \sin (y-h) \nu\right\} \\
& D_{\nu}(\varepsilon)=K^{2} \varepsilon^{2}\left[\nu \cos (\nu h)+B_{0} \sin (\nu h)\right]^{2}+\nu^{2}\left[\nu \sin (\nu h)-B_{0} \cos (\nu h)\right]^{2}, \quad \nu=\sqrt{(\varkappa-1) \xi^{2}+\varkappa \varepsilon^{2}}
\end{aligned}
$$

(2) $\varkappa<1$ で $\varepsilon \leq \varepsilon_{0}=\xi \sqrt{(1-\varkappa) / \varkappa}$ のとき

$S_{\varepsilon}^{(1)}(y)=\frac{K \varepsilon u}{D_{u}(\varepsilon)}\left\{\left[u \operatorname{ch}(u h)+B_{0} \operatorname{sh}(u h)\right] \operatorname{ch}(h-y) u-\left[u \operatorname{sh}(u h)+B_{0} \operatorname{ch}(u h)\right] \operatorname{sh}(h-y) u\right\}$

$S_{\varepsilon}^{(2)}(y)=\frac{u}{D_{u}(\varepsilon)}\left\{K \varepsilon\left[u \operatorname{ch}(u h)+B_{0} \operatorname{sh}(u h)\right] \cos (y-h) \varepsilon-u\left[u \operatorname{sh}(u h)+B_{0} \operatorname{ch}(u h)\right] \sin (y-h) \varepsilon\right\}$

$D_{u}(\varepsilon)=u^{2}\left[u \sinh (u h)+B_{0} \cosh (u h)\right]^{2}+K^{2} \varepsilon^{2}\left[u \cosh (u h)-B_{0} \sinh (u h)\right]^{2}, \quad u=\sqrt{(1-\varkappa) \xi^{2}-\varkappa \varepsilon^{2}}$

$3 ・ 3$ ステップ状变動摩擦係数による熱応力解 式 $(20)$ の温度によって生じる非定常熱応力 $\left\{{ }^{s} \sigma_{p q}^{(j)}\right\}$ は, 熱弾性 ポテンシャル $\Omega^{(j)}$ と Boussinesq の調和応力関数 $\varphi_{0}^{(j)} ， \varphi_{3}^{(j)}$ を用いて次式のように表される.

$$
\begin{aligned}
& \frac{{ }^{s} \sigma_{x x}^{(j)}}{2 G_{j}}=\frac{\partial^{2} \Omega^{(j)}}{\partial x^{2}}+\frac{\partial^{2} \varphi_{0}^{(j)}}{\partial x^{2}}+y \frac{\partial^{2} \varphi_{3}^{(j)}}{\partial x^{2}}-2 \nu_{j} \frac{\partial \varphi_{3}^{(j)}}{\partial y}-\Gamma_{j} T_{s}^{(j)} . \\
& \frac{{ }^{s} \sigma_{y y}^{(j)}}{2 G_{j}}=\frac{\partial^{2} \Omega^{(j)}}{\partial y^{2}}+\frac{\partial^{2} \varphi_{0}^{(j)}}{\partial y^{2}}+y \frac{\partial^{2} \varphi_{3}^{(j)}}{\partial y^{2}}-2\left(1-\nu_{j}\right) \frac{\partial \varphi_{3}^{(j)}}{\partial y}-\Gamma_{j} T_{s}^{(j)} \\
& \frac{{ }^{s} \sigma_{x y}^{(j)}}{2 G_{j}}=\frac{\partial^{2} \Omega^{(j)}}{\partial x \partial y}+\frac{\partial^{2} \varphi_{0}^{(j)}}{\partial x \partial y}+y \frac{\partial^{2} \varphi_{3}^{(j)}}{\partial x \partial y}-\left(1-2 \nu_{j}\right) \frac{\partial \varphi_{3}^{(j)}}{\partial x} \\
& \frac{{ }^{s} \mathcal{U}_{x}^{(j)}}{c}=\frac{\partial \Omega^{(j)}}{\partial x}+\frac{\partial \varphi_{0}^{(j)}}{\partial x}+y \frac{\partial \varphi_{3}^{(j)}}{\partial x} \text {. } \\
& \frac{s_{\nu_{y}^{(j)}}}{c}=\frac{\partial \Omega^{(j)}}{\partial y}+\frac{\partial \varphi_{0}^{(j)}}{\partial y}+y \frac{\partial \varphi_{3}^{(j)}}{\partial y}-\left(3-4 \nu_{j}\right) \varphi_{3}^{(j)}
\end{aligned}
$$

式(20)の温度解に対応し，熱弾性ポテンシャルは次式のように表すことができる.

$$
\begin{aligned}
& \Omega^{(j)}=\frac{\Gamma_{j} T^{*}}{\delta_{k}^{(j)}} \frac{2}{\pi} \int_{0}^{\infty} P_{1}(\xi)\left\{2 \delta_{01}^{K} \sum_{n=1}^{N_{\xi}} \frac{r_{n} R_{n}^{(j)}(y)}{\left(\xi^{2}+r_{n}^{2}\right)^{2} f_{0}\left(r_{n}\right)}\left[e^{-\left(\xi^{2}+r_{n}\right) \tau}-1\right]\right. \\
& \left.+\frac{2}{\pi \varkappa} \int_{0}^{\infty} \frac{\varepsilon S_{\varepsilon}^{(j)}}{\left(\xi^{2}+\varepsilon^{2}\right)^{2}}\left[e^{-\kappa\left(\xi^{2}+\varepsilon^{2}\right) \tau}-1\right] \mathrm{d} \varepsilon\right\} \cos (x \xi) \mathrm{d} \xi
\end{aligned}
$$

また, 応力関数 $(l=0,3)$ を次式のように表す.

$$
\varphi_{l}^{(j)}=\int_{0}^{\infty}\left\{A_{l}^{(j)} e^{-\xi y}+C_{l}^{(j)} e^{\xi y}\right\} \cos (x \xi) \mathrm{d} \xi
$$

式 (32)，(33)を式(27)〜 (31)に代入すれば熱応力の一般解が求まり, 未定定数 $A_{i}^{(j)}, C_{l}^{(j)}$ は, 表面自由および境界 
条件式(11)～(15) より導かれる連立方程式により決定され, $\left\{{ }^{5} \sigma_{p q}^{(j)}\right\}$ を求めることができる.

\section{4. ホワイトメタルのしゅう動摩擦実験}

本しゅう動摩擦実験(7)に使用した試験片は, FCD 400 製円筒状台金に, WJ 7 製ホワイトメタルを 遠心鋳造法によりライニングした船舶用軸受より作成 した。試験片形状を図 2 に示す。また，その機械的性 質を表 1 に, 化学成分を表 2 に示す。なお，ポアソン 比は WJ 7 では $\nu_{1}=0.32, \mathrm{FCD} 400$ では $\nu_{2}=0.3$ であ る。本実験では試験片としゅう動させる回転軸(回転 速度 $n[\mathrm{rpm}])$ として, 炭素鋼 S $45 \mathrm{C}$ を用いた。また, 実際のしゅう動実験の負荷荷重の $1 / 3$ 程度の予荷重を 負荷してしゅう動予備実験を行い, WJ 7 の表面を観 察することにより, 試験片と軸のしゅう動部接触面積 を推定した。その結果，しゅう動部接触部の長さ $2 c$ $=12 \mathrm{~mm}$, 幅 $B=9.8 \mathrm{~mm}$ であった. 実際の試験片は 図 2 に示すように, WJ 7 のしゅう動部接触部分のみ を残し他の部分は切除した。なお，試験開始前のホワ イトメタル表面粗さは $R a=1.4 \mu \mathrm{m}, \mathrm{S} 45 \mathrm{C}$ 軸の表面 粗さは $R a=0.35 \mu \mathrm{m}$ であった. 図 3 にはしゅう動摩 擦試験機の模式図を示す。しゅう動摩擦実験は試験片

Table 1 Mechanical properties

(a) $\mathrm{FCD} 400$

\begin{tabular}{|c|c|c|}
\hline $\begin{array}{c}\text { Tensile } \\
\text { strength } \\
(\mathrm{MPa})\end{array}$ & $\begin{array}{c}\text { Compressive } \\
\text { strength (0.125\%) } \\
(\mathrm{MPa})\end{array}$ & $\begin{array}{c}\text { Young s } \\
\text { modulus } \\
(\mathrm{GPa})\end{array}$ \\
\hline 400 & 250 & 157 \\
\hline
\end{tabular}

(b) $\mathrm{WJ} 7$

\begin{tabular}{|c|l|l|c|}
\hline $\begin{array}{c}\text { Tensile } \\
\text { strength } \\
(\mathrm{MPa})\end{array}$ & $\begin{array}{l}\text { Compressive } \\
\text { strength } \\
(0.125 \%)(\mathrm{MPa})\end{array}$ & $\begin{array}{l}\text { Proportional } \\
\text { limit in } \\
\text { compression } \\
(\mathrm{MPa})\end{array}$ & $\begin{array}{c}\text { Young s } \\
\text { modulus } \\
(\mathrm{GPa})\end{array}$ \\
\hline 72.3 & 25.51 & 15 & 33.35 \\
\hline
\end{tabular}

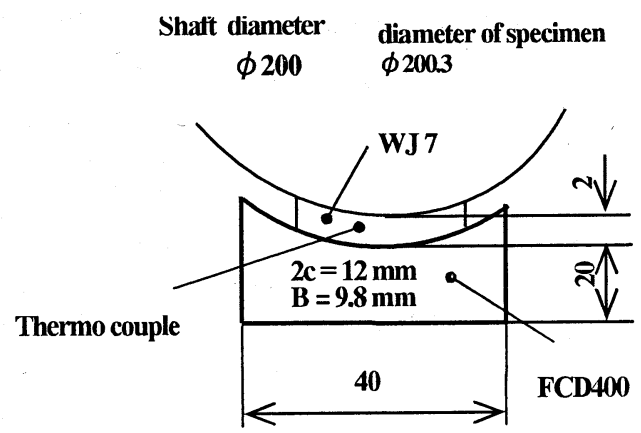

Fig. 2 Shape and dimentions of the specimen
に圧縮静荷重 $P$ を負荷しながら行い, 軸下部の油槽 に軸を浸漬させ, 軸の回転によって潤滑油がしゅう動 部にかきあげられる潤滑機構を採用した。使用した潤 滑油は MOBIL DTE VG 100 heavy(粘度 $95 \times 10^{-6}$ $\mathrm{m}^{2} / \mathrm{s}$ ) である. 試験片しゅう動部から $1 \mathrm{~mm}$ 下の箇所 に,アルメル・クロメル製熱電対を設置することによ って, しゅう動過程中の試験片の温度変化を, また, アルミニウム合金製の試験片の支持部にひずみゲージ を張り付けることによって, しゅう動過程中の摩擦力 $F$ を連続的に測定した。ひずみ測定には，曲げひずみ 除去のため 2 ゲージ法を用い, 動ひずみ計とパーソナ ルコンピュータを用いて自動計測を行った。

ここで, 実際のしゅう動実験の負荷荷重を $P$ とす れば, 摩擦係数 $f$ は $f=F / P$ の関係式より得られる. また, 本実験での接触応力は公称平均応力 $\sigma_{\text {mean }}=$ $P /(2 c B)$ を用いて表示したが, 実際にはへルツ接触圧 力分布になっていると考えられ，数值計算においては， ヘルツの最大接触圧力 $P_{0}$ を $P_{0}=4 \sigma_{\text {mean }} / \pi$ で与えた.

\section{5. 摩擦係数の実験結果と温度変動}

図 4, 5 には公称平均接触応力が $\sigma_{\text {mean }}=30 \mathrm{MPa}$ で, 回転速度がそれぞれ $n=260,500 \mathrm{rpm}$ の場合につい

Table 2 Chemical compositions (a) $\mathrm{FCD} 400$

\begin{tabular}{|c|c|c|c|c|c|}
\hline $\mathrm{C}(\%)$ & $\mathrm{Si}(\%)$ & $\mathrm{Mn}(\%)$ & $\mathrm{P}(\%)$ & $\mathrm{S}(\%)$ & $\mathrm{Mg}(\%)$ \\
\hline 2.5 & 2.7 & 0.4 & 0.08 & 0.02 & 0.09 \\
Min. & Max. & Max. & Max. & Max. & Max. \\
\hline
\end{tabular}

(b) $\mathrm{WJ} 7$

\begin{tabular}{|c|c|c|c|}
\hline $\mathrm{Sn}(\%)$ & $\mathrm{Sb}(\%)$ & $\mathrm{Cu}(\%)$ & $\mathrm{Pb}(\%)$ \\
\hline $11-13$ & $13-15$ & 1.0 & Bal. \\
\hline
\end{tabular}

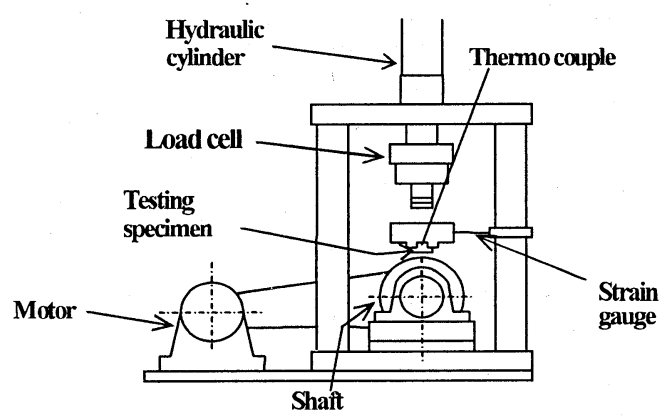

Fig. 3 Schematic illustration of the test-machine 
て, 図 6 には $\sigma_{\text {mean }}=20 \mathrm{MPa} て ゙$, 回転速度が $n=718$ rpm の各場合について, それぞれ摩擦係数の実験結果 を○印で, 深さ $1 \mathrm{~mm}$ における室温との温度差 $\Delta T$ の測定結果をの印で示してある. 式 (1)の摩擦係数の 変動 $F(\tau)$ に本実験デー夕を適用し, 式 $(20)$ を用いて 式(17)のデュアメル積分を畳み込み則を用いて数值的 に求めれば, 本実験のように, 摩擦係数が変動した場 合の温度変動の理論計算結果が得られる。理論計算は 実験に対応して, 表面中心下 $1 \mathrm{~mm}$ の点での温度変動 を求めた。数值計算に用いる熱的物性値としては, WJ 7 については表 2 の化学成分を参考に純金属の熱 的物性值 ${ }^{(8)}$ 加算出し, $\varkappa_{1}=26 \mathrm{~mm}^{2} / \mathrm{s}, K_{1}=41 \mathrm{~W} /$ $(\mathrm{m} \cdot \mathrm{K}) ， \alpha_{1}=25.5 \times 10^{-5} / \mathrm{K}$ を得た。また, 計算に用 いる $\mathrm{FCD} 400$ の熱的物性值(8) として, $\varkappa_{2}=6 \mathrm{~mm}^{2} / \mathrm{s}$, $K_{2}=20 \mathrm{~W} /(\mathrm{m} \cdot \mathrm{K}) ， \alpha_{2}=11.9 \times 10^{-6} / \mathrm{K}$ を採用した。

なお式 ( 5 ) の摩擦熱の大きは $T^{*}$ は, 求めた温度変 動の理論値の大きさが, 温度の実験結果と定量的にほ ぼ等しくなるように決めた。また, ビオ数 $B_{0}$ につい ては, 比較的安定した潤滑状態が得られている図 4,5 において, 温度の理論值の変動が実験値の変動と定性 的にほぼ一致するように決めた。 その結果 $B_{0}=2$ を

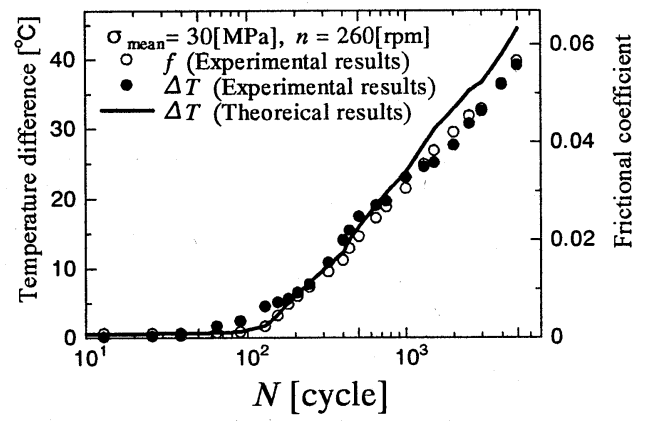

Fig. 4 Variation of temperature and frictional coefficient $\left(\sigma_{\text {mean }}=30 \mathrm{MPa}, n=260 \mathrm{rpm}\right)$

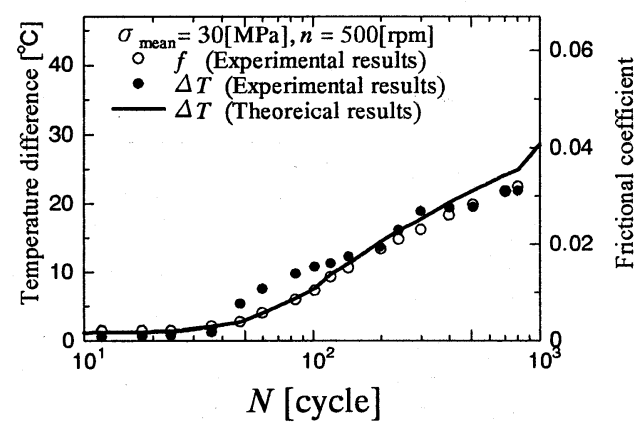

Fig. 5 Variation of temperature and frictional coefficient $\left(\sigma_{\text {mean }}=30 \mathrm{MPa}, n=500 \mathrm{rpm}\right)$
得た。なお,このビオ数の值 $\left(B_{0}=2\right)$ は, 初期温度 $T_{i}$ の半無限体の表面が $0{ }^{\circ} \mathrm{C}$ の媒質で泠却された場合の温 度の計算結果 ${ }^{(9)}$ を参照すれば, 初期温度 $T_{i} を \eta=$ $100, B_{0}=0$ (断熱)の場合の温度結果と仮定し，この計 算結果に実際の温度の実験結果を適用することによっ ても確認することができる。このビオ数の值 $\left(B_{0}=2\right)$ を実際の熱伝達率に換算すれば, $\gamma_{1}=13667 \mathrm{~W} /\left(\mathrm{m}^{2}\right.$ ・ $\mathrm{K})$ となり,この值は実際に流体で冷却されている場 合の熱伝達率の範囲となり ${ }^{(9)}$, 本しゅう動摩擦実験の 冷却条件と矛盾していないことがわかる．以上のよう にして計算された温度変動の理論結果を, 図 4〜6に それぞれ実線で示す。ここで, 図 6 において温度の実 験値(黒丸) と理論值(実線)を比較すると, 図 4, 5 ほど には一致していない。これは, 本試験機では軸回転に より油槽より潤滑油をかきあげ試験片しゅう動部に供 給しているが，軸回転数を $n=718 \mathrm{rpm}$ と速くすると， 軸に付着した潤滑油に作用する遠心力が大きくなり， 試験片しゅう動部への潤滑油の供給が減少し, 安定し た潤滑状態が得られなくなるため, 温度の実験值が理 論值よりも少し大きくなるものと思われる，いずれの 場合も, 温度と摩擦係数の縦軸が $T / f=735.3^{\circ} \mathrm{C}$ とな る一定のスケール比のもとで, 温度の理論值と摩擦係 数は定性的にも定量的にもよい一致が見られる.この ことより, 温度変動の測定結果を用いることで, 変動 摩擦係数の推定が可能であることがわかる。な扔, 図 2 のような接触部以外のコーティング部を切り取った 有限長さの実験モデルと, 図 1 のような無限に長い被 覆半無限体の理論解析モデルでは, 厳密には対応して いないが, 接触中心部表面下 $1 \mathrm{~mm}$ の点の温度と接触 部の摩擦係数のみを問題にする場合には, 測定点から 離れた全体のモデルの相違はあまり大きく影響しない ものと思われる。

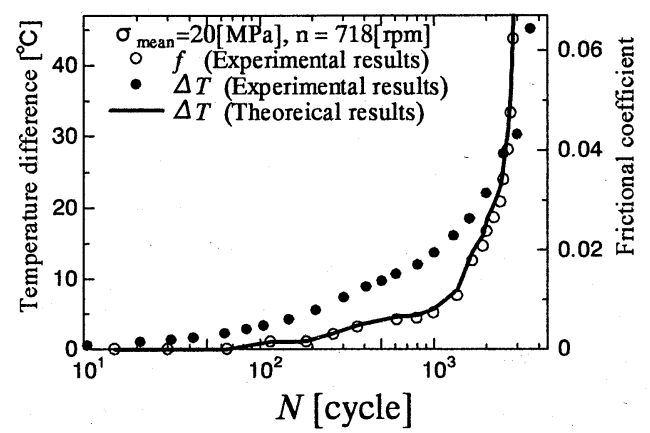

Fig. 6 Variation of temperature and frictional coefficient $\left(\sigma_{\text {mean }}=20 \mathrm{MPa}, n=718 \mathrm{rpm}\right)$ 


\section{6. 応力変動の数値計算結果}

図 7,8 には公称平均接触応力が $\sigma_{\text {mean }}=30 \mathrm{MPa}$ で, 回転数がそれぞれ $n=260,500 \mathrm{rpm}$ の場合について, 図 9 には $\sigma_{\text {mean }}=20 \mathrm{MPa}$ で, 回転数が $n=718 \mathrm{rpm}$ の 各場合について, それぞれ $x$ 方向応力 $\sigma_{x x}$ の変動を示 す. 結果はすべて温度の測定点に対応し, 表面下 1 $\mathrm{mm}$ の深さにおける值を示す。応力は実験から得ら れる摩擦係数の変動を用いて, 図 1 の被覆半無限体モ デルについて計算しているので, 図 2 のような有限長 さの実験モデルに対しては，この応力解は厳密には対 応していない.しかし，接触中心部表面下 $1 \mathrm{~mm} の$ 点 の応力変動のみを問題にする場合には, サン・ブナン の原理より, 全体のモデルの相違はあまり大きく影響 せず，図 7〜9 は実験モデルに対しても適用できるも のと思われる：図 7〜9においていずれの場合も，被

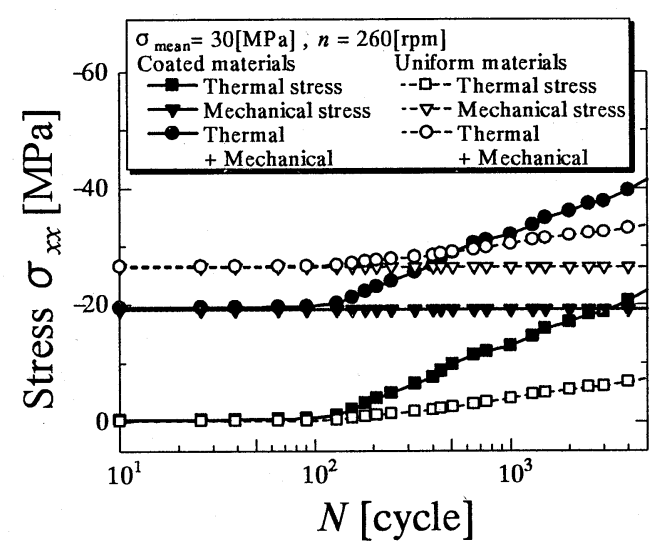

Fig. 7 Variations of $\sigma_{x x}$ for thermal and mechanical stresses $\left(\sigma_{\text {mean }}=30 \mathrm{MPa}, n=260 \mathrm{rpm}\right)$

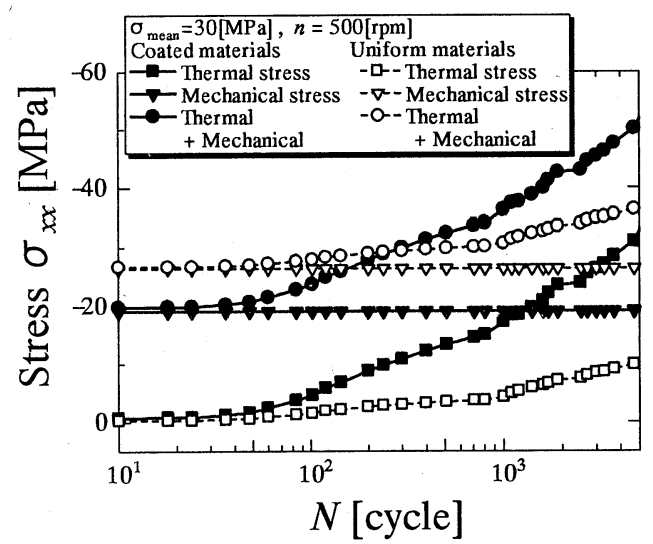

Fig. 8 Variations of $\sigma_{x x}$ for thermal and mechanical stresses $\left(\sigma_{\text {mean }}=30 \mathrm{MPa}, n=500 \mathrm{rpm}\right)$
覆材について，摩擦熱による熱応力を口印で，機械的

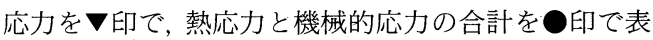
す。また比較のため, FCD 400 から成る均一材につい ても，熱応力を $\square$ 印で，機械的応力を $\nabla$ 印で, 熱応力 と機械的応力の合計を○印で示してある. 接触圧力 $P_{1}(x)$ が時間的に変化しないので, 機械的応力も変動 せず一定值となっているが, 熱応力は初期值 0 から摩 擦係数に対応して時間とともに増加している.特に図 7 では 3000 cycle, 図 8 では 1400 cycle, 図 9 では 2200 cycle 以上になると, 熱応力が機械的応力よりも 大きくなり, 熱応力が全応力の半分以上を占めるよう になる。一方 FCD 400 から成る均質材の熱応力は, 被覆材の熱応力よりも常に小さく約 $1 / 3$ 程度の大きさ となっており, 本数值計算の範囲では, 均質材の機械 的応力は熱応力よりも常に大きくなっている。また， 最初は被覆材の全応力は均質材のそれよりも小さい が, 被覆材の全応力は時間の経過とともに大きくなり, 特に図 7 では 500 cycle, 図 8 では 200 cycle, 図 9 で は 1400 cycleを超えると均質材のそれよりも大きく なり，それらの差は時間とともに著しくなる，これは， FCD 400 の線膨張係数が $\alpha_{2}=11 \times 10^{-6} / \mathrm{K}$ と, WJ 7 の 線膨張係数の半分以下の值なので, 温度が大きくなる ほど, 線膨張係数の差に起因して生じる被覆材の圧縮 熱応力が大きくなるためと思われる.

\section{7. 結言}

摩擦係数が変動するしゅう動接触による被覆材の温 度, および非定常熱応力ならびに機械的応力を解析し, FCD 400 を台金としたWJ 7 ホワイトメタル被覆材の しゅう動摩擦実験と比較することにより，本実験例の 範囲および数値計算例の範囲で, 以下の結論を得た。

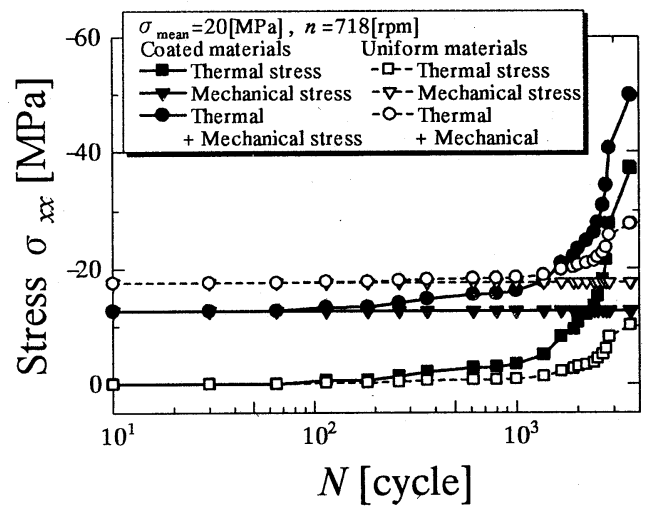

Fig. 9 Variations of $\sigma_{x x}$ for thermal and mechanical stresses $\left(\sigma_{\text {mean }}=20 \mathrm{MPa}, n=718 \mathrm{rpm}\right)$ 
(1) 摩擦熱による温度変動の值と変動摩擦係数の 値は，接触圧力や回転速度にかかわらず，ほぼ一定の 比で表すことができ, 温度変動の測定結果を用いて変 動摩擦係数の推定が可能である.

（2）熱応力は時間とともに増大し，回転数が 1000〜3000 cycle を超えると，機械的応力よりも熱 応力が大きくなり；その差は時間の経過とともに著し くなって, 時間の経過とともに, 熱応力が全応力中で 大きな割合を占めるようになる。

（3） FCD 400 から成る均質材の熱応力は, WJ 7 ホワイトメタル被覆材の熱応力よりも常に小さく, 約 $1 / 3$ 程度の大きさとなる。

最後に, 本研究に協力いただいた当時富山大学工学 部学生であった佐伯亜紗子君, 森田純子君, 河端宏和 君に感謝する.

\section{文献}

(1) Ju, F. D. and Chen, T. Y., Thermomechanical Cracking in Layered Media From Moving Friction Load. Transactions of the ASME, Journal of Tribology, Vol. 106 (1984), pp. 513-518

(2) Ju, F. D. and Liu, J. C., Effect of Peclet Number in
Thermo-Mechanical Cracking Due to High-Speed Friction Load, Transactions of the ASME, Joumal of Tribology, Vol. 110 (1988), pp. 222-227.

( 3 ) Chen, L. S. and Chu, H. S., Transient Thermal Stresses Due to Periodic Moving Frictional Load in Layered Media, Journal of Thermal Stresses, Vol. 12 (1989), pp. 169-189.

(4) Molinari, A. et al., Dependence of the Coefficient of Friction on the Sliding Conditions in the High Velocity Range, Transactions of the ASME, Journal of Tribology, Vol. 121 (1999), pp. 35-41.

(5) Liu, G. and Wang, Q., Thermoelastic Asperity Contacts. Frictional Shear, and Parameter Correlations, Transactions of the ASME, Journal of Tribology, Vol. 122 (2000), pp. 300-307.

(6) Liu, S. and Wang, Q., A Three-Dimensional Thermomechanical Model of Contact Between Non-Conforming Rough Surfaces, Transactions of the ASME, Joumal of Tribology, Vol. 123 (2001), pp. 17-26.

(7) Tamura, K. et al., Effect of both Shaft-revolutionspeed and Frictional Stresses on the Cut-off Fatigue Lives in the White-metal Sliding Bearing, Journal of The Japan Institution of Marine Engincering, Vol. 37, No. 8 (2002), pp. 31-37.

(8) The Japan Society of Mechanical Engineers ed, JSME Date Handbook: Heat Transfer, 4 th ed., (1986), p. 314, The Japan Society of Mechanical Engineers.

( 9 ) Holman, J. P. and Hirata, K., translate into Japanese, Heat Transfor, (1982), p. 13, 98, Brain Book Company. 